\title{
Reference beyond (and without) the Reference Desk
}

\author{
Barbara J. Ford
}

Is the reference desk still the contact point where most academic library users find the services, information, and assistance they need? The author proposes that the reference desk as the center of reference service in academic libraries is an assumption that should be examined in light of new technologies and changes in the way people find and use information. An alternative or supplementary model is delineated.

n 1876 Samuel Green stated in American Library Journal that "personal intercourse and relations between librarians and readers are useful in all libraries."' Samuel Rothstein's 1955 publication, The Development of Reference Services, provides an excellent overview of how current reference service originated and developed in the period from 1850 to $1940 .^{2}$ Rothstein's discussion of reference services includes personal interactions, but only mentions in passing the reference desk as the organizational pattern for delivery of these services.

By the 1984 ACRL Conference at the Alternative Format presentation, "A House Divided: Public Service Realities in the 1980 s," an assumption of those addressing the challenges and changes facing reference services was that the reference desk is the center of this assistance. Speakers seemed to support Patricia Swanson's viewpoint that "the reference desk represents the critical mass of resources-human, printed, and now electronic, so configured for a convenient and predictable location so that library patrons can find the service and can find someone to help them. ${ }^{\prime \prime 3}$ Even those presentations that were supposedly the most questioning and untraditional assumed that the reference desk is an important component of reference service.

A survey of the literature shows that few authors have questioned this assumption. One of those who has, Thelma Freides, brought up this point in 1983 when she stated, "Equally unarticulated and unexamined is the assumption that the hub of this assistance is the reference desk, where a reference librarian, or surrogate, is available to the reader at all times. The arrangement conveys an implicit promise never to let the reader go unserved, but it also pegs the service at a low level. ${ }^{\prime \prime 4}$ In 1985, in a symposium about reference work in The Journal of Academic Librarianship, Mary Biggs' proposal to cut the number of desk hours in order to provide other service met with an enthusiastic response. ${ }^{5}$ The reference desk appears to be a sacred library tradition that many librarians are unwilling or unable to relinquish or question.

Some authors have begun to address the need to question assumptions relating to library programs and services. Nina Matheson says, "We must ask ourselves some very hard questions. What have we been failing at that we had better stop doing or do differently? How long have we been trying to get people to come to the library, to use the library? . . . Do our solutions really respond to information access problems?'" While not talking specifically

Barbara J. Ford is Associate Director at Trinity University Library, San Antonio, Texas 78284. This paper was presented at the ACRL Fourth National Conference in Baltimore, April 9-12, 1986. 
about the reference desk, Matheson's challenge is certainly applicable to those of us concerned with the future of reference services. Patricia Battin, in discussing the library as the center of the restructured university, notes, "The weight of our historic traditions is such that we tend to find it very difficult to look at the future in terms of a vastly changed organizational structure. ${ }^{\prime 7}$ Richard De Gennaro suggests, "Libraries need to develop new goals and new strategies based on new technologies .... or risk becoming mere symbols of culture and museums of the book."

The reference desk, as the center and "given" of reference service, is one of the traditions that should be examined. $\mathrm{Li}$ braries have changed dramatically in collection size, in physical space, and in the heterogeneous nature of collections and of library users since the time when the reference desk became a common fixture in libraries. Reference desk service may have been more useful in simpler days of smaller collections and buildings and may be more necessary in public libraries. Indeed, there would seem to be a tension between a general desk and subject specialization, a topic that is hinted at but never explicitly addressed in Rothstein's history of the development of reference service.

"Renaissance" reference librarians serving all comers at a reference desk may no longer be a realistic solution for providing public services for patrons. Has what happens at the reference desk made general users less self sufficient and more dependent on library staff? The historic tradition of the reference desk makes it difficult for reference librarians and those studying and discussing reference to think of library services without the reference desk as a given for providing service and user interface. On the other hand, much that is written indicates that the reference desk does not provide the most effective and efficient service, and therefore we must consider alternatives.

William Miller has written, "Objective analysis of reference desk service indicate the cost of pretending that we can continue to do everything for everybody, and do it well. This is an organizational fiction which needs to be discarded. Our success is turning into failure, and we must acknowledge this reality in order to cope with it." "The time has come when librarians must define their clientele and then decide whom they can best assist with various services. Freides says,

The reference desk works best for directional questions and requests for specific factual information. It is not well designed for dealing with questions requiring interpretation or exploration. . . . Studies of user behavior indicate that users indeed perceive the reference service as intended for simple questions and quick replies. ... By establishing the desk as the focal point of reader assistance, libraries not only expend professional time on trivial tasks, but also encourage the assumption that the low-level, undemanding type of question handled most easily and naturally at the desk is the service norm. ${ }^{10}$

Academic librarians must ask whether their clientele really need a reference desk or whether other services would meet their needs in a more effective manner. Without spending so much time and energy providing service from a reference desk, could we as librarians devote our efforts more effectively to developing more appropriate and useful services for our primary clientele? Brian Nielsen has provided a perspective on many library services, including the reference desk, when he notes that because reference service "has seen little, if any, design change since its origin in the late nineteenth century, librarians tend not to think of the value choices implicit in that design that they have also inherited. They all accept as a basic postulate that reference service is useful to anyone, at least potentially." 11

The reference desk in academic libraries needs evaluation based on new technologies and changes in the way people find and use information and the role of libraries in this process. Rao Aluri and Jeffery St. Clair have suggested that "experiments could be conducted to see if much of the information supplied at the reference desk could be made accessible through computers and other means." Much has been written about the importance of user education, bibliographic instruction, point-of-use aids and other 
means to assist users in libraries beyond the reference desk. Dana Smith and Steve Hutton report on their successful "use of uniquely developed microcomputer programs to provide reference service to patrons at points throughout the library at all hours, but intended to support service at times when reference personnel are not available." ${ }^{13}$ This at least is a beginning. While being hesitant to eliminate face-toface personal interaction between librarians and patrons, reference librarians need to begin to think what has heretofore been the unthinkable, exploring alternatives and possibly eliminating the reference desk. In accordance with what is being written and discussed at meetings, the present configuration does not satisfy either librarians or library users. It appears there is a problem; by looking for different models, alternatives can be explored.

To assist the development of possible alternative or supplementary models to the reference desk, an alternative model is delineated here. It is not disputed that service should continue or that people need assistance in using libraries. The question is whether such assistance is any longer most efficiently and effectively provided from a reference desk.

A theoretical model for future reference service might replace the desk and librarian with a computer terminal where users could $\log$ requests and receive answers and appropriate printed handouts. Many questions answered at reference desks could be programmed for quick response; other questions might require interaction with the user, either in person, by telephone or through the computer terminal. For frequently asked questions, such as which source on a bibliography is the best place to begin, annotations and suggestions could be provided on a terminal; and if assistance is still required, the office hours of a librarian with expertise on the subject could be provided. Directional and other general questions, such as how to use the catalog or indexes, and how to find periodicals, could be handled through a terminal or printed matter. Librarians could be available much like teaching faculty, by appointment, for certain hours each week in their office.
What would happen if reference desks were closed? Would users be terribly frustrated by not having a readily available person to talk to when questions arise, or would they begin to answer simple requests for themselves, or carefully read written aids and handouts, or pay more attention at presentations? Would academic institutions be able and willing to cope with the consequences of possible frustration and changed service patterns? Would reference librarians become more productive, respected members of the academic community? Would reference librarians be willing and able to accept the challenge? Should librarians support a model that takes away the personal communication between librarian and user at a reference desk? Has the reference desk seen its most useful time and will other patterns better meet user needs?

If reference desks were closed, librarians might be astonished at either how little people missed the service or how terribly frustrated patrons would be in trying to use the library. Faculty accustomed to a traditional library setting would probably be disturbed, as most people are by changes, but librarians working with faculty in other ways could fill these needs. Librarians could be available for classroom presentations and collaboration with faculty to integrate library use into instructional programs. Students who have grown up playing computer games and solving problems with computers might find new services and models more to their liking. In the academic setting, librarians could work with faculty and provide assistance and guidance for students on which sources and approaches are most useful. In short, they could use to their advantage, and their clientele's, the structure inherent in the academic environment. With more time librarians could seriously address new ways to meet the needs of the primary clientele that may not necessarily be effectively served at a reference desk.

So long as the reference desk model is uncritically accepted, librarians are not challenged to respond creatively to changes in materials, formats, and research opportunities for our users, and us- 
ers are not challenged to use any of a variety of printed or computerized sources or aids. Librarians must come to grips with these disturbing notions, question their basic assumptions and begin to think about alternatives to the reference desk as the center of reference service. As Rothstein's account makes clear, in the late nineteenth and early twentieth centuries there were a number of ways to provide direct personal assistance. The current literature and modern technology present even more alternatives. Various models and possible alternatives are needed to explore the energies for transition to new service patterns beyond and perhaps without the reference desk.

\section{REFERENCES}

1. Samuel S. Green, "Personal Relations between Librarians and Readers," American Library Journal 1:79 (Nov. 30, 1876).

2. Samuel Rothstein, The Development of Reference Services through Academic Traditions, Public Library Practice and Special Librarianship (Chicago: Assn. of College and Research Libraries, 1955), ACRL Monographs, no.14.

3. Patricia K. Swanson, "Traditional Models: Myths and Realities," in Academic Libraries: Myths and Realities-Proceedings of the Third National Conference of the Association of College and Research Libraries (Chicago: Assn. of College and Research Libraries, 1984), p.89.

4. Thelma Freides, "Current Trends in Academic Libraries," Library Trends 31:466-67 (Winter 1983).

5. Mary Biggs, "Replacing the Fast Fact Drop-In with Gourmet Information Service: A Symposium," Journal of Academic Librarianship 11:68-78 (May 1985).

6. Nina W. Matheson, "The Academic Library Nexus," College \& Research Libraries 45:208 (May 1984).

7. Patricia Battin, "The Library: Center of the Restructured University," College \& Research Libraries 45:171 (May 1984).

8. Richard De Gennaro, "Libraries \& Networks in Transition: Problems and Perspectives for the 1980s," Library Journal 106:1049 (May 15, 1981).

9. William Miller, "What's Wrong with Reference: Coping with Success and Failure at the Reference Desk," American Libraries 15:322 (May 1984).

10. Friedes, "Current Trends in Academic Libraries," p.467.

11. Brian Nielsen, "Teacher or Intermediary: Alternative Professional Models in the Information Age," College \& Research Libraries 43:186 (May 1982).

12. Rao Aluri and Jeffrey W. St. Clair, "Academic Reference Librarians: An Endangered Species?'” Journal of Academic Librarianship 4:84 (May 1978).

13. Dana E. Smith and Steve M. Hutton, "Back at 8:00 AM-Microcomputer Library Reference Support Programs," Collegiate Microcomputer 11:289 (Nov. 1984.) 